\title{
Heritage of Arabic Language in South Caucasus: Arabic Inscriptions From Trialeti
}

\author{
George Narimanishvili \\ Institute of Asia and Africa, Free University of Tbilisi (FUT), Tbilisi, Georgia
}

\begin{abstract}
In this article the author would like to discuss the usage of Arabic language in South Georgia as language of religious and ethnical minority in circumstances of Russian rule. The best examples of this are Arabic inscriptions on gravestones. In this article the author describes several inscriptions from Trialeri, South Georgia, which, because of unknown reasons, have never been studied by scientists before. Another important reason why the author has paid importance to those inscriptions is their recent condition and danger to lose them forever. The author has studied inscriptions from three main cemeteries: Beshtasheni, Tikma-Dash, and Minayasar. As a result of his research the author can say that Arabic language have been used by Muslims of Turk origins in Trialeti till Soviet time. They were using this language to preserve their identity, but it used to work only about a century. Soviet rule tried to destroy all identities and religions and especially after WWII they have reached more or less success. Today the Muslim population of Trialtei does not understand Arabic, they just know that their religion is Islam and in the graves with Arabic inscriptions lay their predecessors.
\end{abstract}

Keywords: Arabic inscription, history of South Caucasus, Arabic language in South Caucasus

\section{Introduction}

A rabic language entered South Caucasus region in the middle of the 7th century A.D. when Arabs have conquered Armenia and made peace agreement with prince of Georgia (Yaqūt al-Hamawiy, 1995, p. 36). The second Arab invasion took place in 735, when Umayyad army leaded by Marwan Ibn Muhammad (in future the last Umayyad Caliph Marwan II) entered South Caucasus (Juansheri, 1995, pp. 233-238; Al-Tabari, 2005, p. 1245; Al-Balāzuriyy, 1987, p. 292). After this time Arabic language spread in this region very fast and had a great influence on local languages, which we can see till the recent times.

As a result of the centuries-old residence of the Muslim population (the Arabs, Seljuks Turks, Mongols, Iranians, Azerbaijanians) on the territory of South Caucasus, numerous Arabic inscriptions have been left at archaeological sites as well as at currently existing settlements. Only a small part of the early inscriptions have been brought to light and studied by researchers. Study of epigraphic monuments is of special importance for elucidation of many questions of the history of the Region. Sometimes they represent the only written sources. They are distinguished by great accuracy of recording of facts and allow ascertaining a number of valuable historical data. In this regard, interest is attached to Arabic epigraphic monuments, which, we believe, have great importance for researching into historical political changes in the history of South Caucasus

George Narimanishvili, Ph.D. student and lecturer of Arabic Language at Institute of Asia and Africa, Free University of Tbilisi, Tbilisi, Georgia. 
as well as identifying the ethno-religious composition of different parts of the region at various stages of history.

Arabic inscriptions from Georgia were studied by Georgian and foreign scientists for a long time (Tsereteli, 2001; Chubinashvili, 1952; Kakhiani, 1965, 1974; Krachkovskaya, 1951; Gviniashvili, 2014; Gviniashvili, 2003).

Arabic inscriptions chronologically cover a very extensive period from the 7th c. A.D. till the 20th c. A.D.

The oldest Arabic inscription in Georgia is from Tbilisi, a milestone dated from the 1st century of Hijra (7th c. A.D.) and was discovered in Seidabad (Tsereteli, 2001, p. 27). Another one is fragment of Arabic inscription included in the Georgian one and is dated from the 3rd century of Hijra (9th c. A.D.) and was discovered in village Machkhani ${ }^{1}$. In 2012 during the excavations of the defense wall of old Tbilisi was discovered a new Arabic inscription which is dated from the 2nd century of Hijra (8th c. A.D.) $)^{2}$. Inscriptions are written in archaic Kufi script without dots and diacritical signs and are partly damaged.

There are also lots of Arabic inscriptions from the later periods in Dmanisi (XIII-XIV cc. A.D.), and other parts of Georgia like Kaheti, Javakheti, Trialeti etc.

Trialeti: In this article the author would like to discuss several Arabic inscriptions from Trialeri, South Georgia, which were revealed during the field explorations. Because of unknown reasons, these inscriptions have never been studied by scientists before. Another important reason why the author has paid importance to those inscriptions is their recent condition and danger to lose them forever.

Trialeti is situated in Southern Georgia, in the north-western part of Lesser Caucasus on 1,600-2,000 above sea level. This land was settled from the ancient times, what is indicated by numerous ancient settlements and architectural sites. Trialeti region played an important geopolitical, economic, and cultural role in South Caucasus. It was the place of intersection of several significant trade routes. In addition, from the military strategic viewpoint, Trialeti was the one key control point of the passes from Lesser Caucasus.

Process of decline in Trialeti started with Mongol conquests, then continued during wars with Tamerlan. As a result of Ottoman conquests and raids from Daghestan at the end of the 17th c. this region almost devastated.

The situation has changed in the 19th c. when this region became a part of Russian empire, with new state language. Resettlement of Trialeti started in 1829, when numerous new settlers of Greek and Armenian origin moved from Ottoman Empire to there. During the Russian rule the region was mostly populated with Greeks and Armenians, but there were also five Azerbaijani, two German and one Georgian village.

Majority of Muslims left the territory and moved to Ottoman Empire or Iran. Nomads of Turk origins were not an exception, but some tribes decided to stay in South Georgia and started new settled life there. In circumstances of Russian and later Soviet rule it was hard for them to preserve their identity and the only way to do it was religion, which main appearance was divine language, The best examples of this are Arabic inscriptions on gravestones. I have studied inscriptions from three main cemeteries: Beshtasheni, Tikma-Dash, and Minayasar.

Tikma-Dash: Graveyard is situated in the beginning of the pass from Trialeti to Javakheti, on the right side of the road. The graveyard contains 120 graves, but only eight of them have gravestones with inscriptions.

\footnotetext{
1 The inscriptionswas read by G. Tsereteli and published by G. Chubinashvili (1952, pp. 443-444).

2 Archaeological and epigraphic report on the inscription was represented in Georgian National Museum by me and prof. M. Dzneladze in 2013.
} 
All inscriptions start with the same formula: "This is a grave of the deceased, forgiven" then the name of the deceased and name of tribe in the end. Just two inscriptions start with part of the 88 verse of the 28 surah: "Everything will be destroyed except His Face. His is the judgement, and to Him you will be returned" (The Qur'an, 2010, 28:88, p. 329). After this verse we read the abovementioned formula. Almost all inscriptions have date. On some inscriptions date is given in the beginning (gravestones \#1;3;4;7) ${ }^{3}$ and on some of them in the end (gravestone \#2;8). In two inscriptions date is not preserved because of damage (gravestones \# 5; 6). The oldest date on Tikma-Dash inscriptions is 1208 A.H. (1793-94 A.D.) and the newest one is 1281 A.H. (1864-65 A.D.). We read the following names of the deceased: Khamaz (gravestone \# 2), Muhammad Khan (gravestone \#3) and Chalib (gravestone \#4). Well readable is a name of tribe-Sarwan. All inscriptions are written with Naskh calligraphy.

All gravestones, except one, are decorated with six leafed flowers, on the gravestone \#3 with flowers there are images of three daggers, on the gravestone \#5 there are images of bindweed and spirals. All images and inscriptions are relief. All gravestones are faced to East.

Beshtasheni: The graveyard is situated south from village Beshtasheni, on Tbilisi-Tsalka roadside. The graveyard contains 23 graves, but only three of them have gravestones with inscription. On the gravestone \#2 we read the formula similar to the Tikma-Dash inscriptions: "This is a grave of the deceased, forgiven" and the inscription of the gravestone \#1 starts with the same verse, which we find in Tikma-Dash inscriptions: "Everything will be destroyed except His Face. His is the judgement, and to Him you will be returned" (The Qur'an, 2010, 28:88, p. 329). Gravestone \#3 is broken and a main piece of the inscription is lost. Gravestones \#1 and \#2 have dates \#1 1267 A.H. (1850-51 A.D.) and \#2 1317 A.H. (1899-1900 A.D.). On the gravestone \#2 we read the name of the deceased Ali Walid Mula, on both \#1 and \#2 gravestones is mentioned name of a tribe Sarwan. Both inscriptions are written with Naskh calligraphy. All three gravestones are ornamented. On the gravestones \#1 and \#2 there are images of six leafed flowers, on the grave stone \#2 there is also image of a dagger. On the gravestone \#3 there is preserved only an image of a gun. All images and inscriptions are relief. All gravestones are faced to East.

Minaiasar: Cemetery is situated on the southern slope of Trialeti mountain range, $5 \mathrm{~km}$ north from village Arjevan Sarvan. Cemetery contains 29 grave and 22 have gravestone with Arabic inscription. Compositions and contents of the inscriptions are different from each other and the ones from Beshtasheni and Tikma - Dash. For example here is used a part of the 156 verse of surah 2: "Indeed we belong to God, and indeed to Him we will return" (The Qur'an, 2010, 2:156, p. 45).

All inscriptions have date, some dates are written in the beginning of the inscription (gravestone \#4; 5; 6) and other ones in the end (gravestones \# 2; 3). The oldest date is 1300 A.H. (1882-3 A.D.) and the most recent one-1912 ${ }^{4}$. We read names of several deceased: Abd Allah (gravestone \#3), Mustafa (gravestone \#5) Muhammad (gravestone \#2) and Hadija (gravestone \#2). Inscriptions are written with Naskh calligraphy. Some gravestones have ornaments. Gravestones \#3 and \#4 have six leafed flowers, \#5 and \#6 hand, crescent and star. On gravestones \#1;2; 3 inscriptions are relief and on \#4; 5; 6 are scratched. All gravestones are faced to East.

\section{Conclusion}

As a result of the study the author has discovered that first two cemeteries used to function in same period

\footnotetext{
3 All numerations are given by the author during the field studies in 2009 and 2013.

${ }^{4}$ Interesting fact is that the date is given in Christian year.
} 
(the end of the 18th and the beginning of the 19th cc. A.D.) and belong to Sarvan people, the nomadic tribe of Turk origin. On another hand Minayasar cemetery is dated from the later period (the end of the 19th the beginning of the 20th cc. A.D.) and also belongs to Sarvan people, but now settled in village Arjevan-Sarvan. As a result of the research the author can say that Arabic language have been used by Muslim of Turk origins in Trialeti till Soviet time. They were using this language to preserve their identity, but it used to work only about a century. Soviet rule tried to destroy all identities and religions and especially after WWII they have reached more or less success. Today the Muslim population of Trialtei does not understand Arabic, they just know that their religion is Islam and in the graves with Arabic inscriptions lay their predecessors.

\section{Sources}

Al-Balāzuriyy. (1987). Futūḥ al-buldān. ḥaqqahu wa sharaḥahu wa 'alaqa ḥawashīhi wa a'adda fahārisahu wa qaddama lahu 'Abd Allah Anis al-Tāài' wa 'Umar Anis al-Tāài'. Bayrūt: mu'assa al-ma'ārif.

The Qur'an (2010). With Sürah Introductions and Appendices. Saheeh International Translation. ed. by A. B. al-Mehri. Birmingham: Maktabah Booksellers and Publishers.

Al-Tabari. (2005). Tārīkh al-umam wa al-mulūk. I'tana bihi Abu Șạ̄īb al-Karami. Bayt al-afkar al-dawliy.

Juansheri. (1955). Ckhovreba Vakhtang Gorgaslisa. Qartlis Ckhovreba, vol. 1, ed. by Simon Kaukhchishvili, Tbilisi.

Yaqūt al-Ḥamawiy. (1995). Mu 'jam al-Buldān, almujallad ath-thāniy. Bayrūt: dar al-șāder.

\section{References}

Chubinashvili, G. (1952). VIII-IX saukuneebis kartul khurotmodzghvrul dzeglta erti rigis datarighebistvis (For dating the one group of Georgian architectural monuments of 8th-9th cc. A.D.). Sakartvelos SSR Metsnierebata Akademiis Moambe, 13(7), 441-447.

Gviniashvili, E. (2014). About some Arabic epitaphs from old Muslim cemetery of Tbilisi. The Near East and Georgia, VIII, 277-282.

Gviniashvili, E. (2003). One Arab inscription from Kiziki. Perspective-XXI V, 112-113.

Kakhiani, Ts. (1965). Dmanisis Arabuli Tsartserebi (Arabic inscriptions from Dmanisi). Tbilisi.

Kakhiani, Ts. (1974). Svetitskhovlis Orenovani Epiatpia (Bilingual Epitaph from Svetitskhoveli). Sakartvelos SSR Akademiis Matsne, 3, 125-130.

Krachkovskaya, V. A. (1951). Nadgrobnie nadpisi iz Dmanisi (Inscriptions on gravestones from Dmanisi). Epigrafika Vostika V, 21-32.

Tsereteli, G. (2001). Semituri enebi da mati mnishvneloba kartuli kulturis istoriis shestsavlistvis (Semitic languages and their importance for study of the history of Georgian culture). Orientalist I, 7-31. 